\title{
The coastal environment and human health: microbial indicators, pathogens, sentinels and reservoirs
}

\author{
Jill R Stewart*1, Rebecca J Gast ${ }^{2}$, Roger S Fujioka ${ }^{3}$, Helena M Solo-Gabriele ${ }^{4}$, J \\ Scott Meschke ${ }^{5}$, Linda A Amaral-Zettler ${ }^{6}$, Erika del Castillo ${ }^{6}$, Martin F Polz ${ }^{7}$, \\ Tracy K Collier ${ }^{8}$, Mark S Strom ${ }^{8}$, Christopher D Sinigalliano ${ }^{9,10}$, \\ Peter DR Moeller ${ }^{1}$ and A Fredrick Holland ${ }^{1}$
}

\begin{abstract}
Address: ${ }^{1}$ Hollings Marine Laboratory, NOAA National Ocean Service, Charleston, SC 29412, USA, ${ }^{2}$ Woods Hole Oceanographic Institution Woods Hole Center for Oceans and Human Health, Woods Hole, MA 02543, USA, ${ }^{3}$ Water Resources Research Center, University of Hawaii, Honolulu, HI 96822, USA, ${ }^{4}$ Rosenstiel School for Marine and Atmospheric Sciences, University of Miami, Miami, Florida 33149, USA,

${ }^{5}$ Department of Environmental and Occupational Health Sciences, University of Washington, Seattle, WA 98105-6099, USA, ${ }^{6}$ The Josephine Bay Paul Center for Comparative Molecular Biology and Evolution, Marine Biological Laboratory, Woods Hole Center for Oceans and Human Health, Woods Hole, MA 02543, USA, ${ }^{7}$ Civil and Environmental Engineering, MIT, Woods Hole Center for Oceans and Human Health, Cambridge, MA 02139, USA, ${ }^{8}$ Northwest Fisheries Science Center, NOAA Fisheries, Seattle, WA 98112, USA, ${ }^{9}$ Atlantic Oceanographic and Meteorological Laboratory, NOAA Office of Oceanic and Atmospheric Research, Miami, FL 33149, USA and ${ }^{10}$ Cooperative Institute of Marine and Atmospheric Studies, University of Miami, Miami, FL 33149, USA

Email: Jill R Stewart* - jill.stewart@unc.edu; Rebecca J Gast - rgast@whoi.edu; Roger S Fujioka - roger@hawaii.edu; Helena M SoloGabriele - hmsolo@miami.edu; J Scott Meschke - jmeschke@u.washington.edu; Linda A Amaral-Zettler - amaral@mbl.edu; Erika del Castillo - edelcastillo@mbl.edu; Martin F Polz - mpolz@mit.edu; Tracy K Collier - tracy.collier@noaa.gov; Mark S Strom - mark.strom@noaa.gov; Christopher D Sinigalliano - christopher.sinigalliano@noaa.gov;

Peter DR Moeller - peter.moeller@noaa.gov; A Fredrick Holland - fred.holland@noaa.gov

* Corresponding author
\end{abstract}

from Centers for Oceans and Human Health Investigators Meeting

Woods Hole, MA, USA. 24-27 April 2007

Published: 7 November 2008

Environmental Health 2008, 7(Suppl 2):S3 doi:10.1 186/1476-069X-7-S2-S3

This article is available from: http://www.ehjournal.net/content/7/S2/S3

(C) 2008 Stewart et al; licensee BioMed Central Ltd.

This is an open access article distributed under the terms of the Creative Commons Attribution License (http://creativecommons.org/licenses/by/2.0), which permits unrestricted use, distribution, and reproduction in any medium, provided the original work is properly cited.

\begin{abstract}
Innovative research relating oceans and human health is advancing our understanding of diseasecausing organisms in coastal ecosystems. Novel techniques are elucidating the loading, transport and fate of pathogens in coastal ecosystems, and identifying sources of contamination. This research is facilitating improved risk assessments for seafood consumers and those who use the oceans for recreation. A number of challenges still remain and define future directions of research and public policy. Sample processing and molecular detection techniques need to be advanced to allow rapid and specific identification of microbes of public health concern from complex environmental samples. Water quality standards need to be updated to more accurately reflect health risks and to provide managers with improved tools for decision-making. Greater discrimination of virulent versus harmless microbes is needed to identify environmental reservoirs of pathogens and factors leading to human infections. Investigations must include examination of microbial community dynamics that may be important from a human health perspective. Further research is needed to evaluate the ecology of non-enteric water-transmitted diseases. Sentinels should also be
\end{abstract}


established and monitored, providing early warning of dangers to ecosystem health. Taken together, this effort will provide more reliable information about public health risks associated with beaches and seafood consumption, and how human activities can affect their exposure to diseasecausing organisms from the oceans.

\section{Introduction}

Bodies of water, particularly the coastal oceans and the Great Lakes, provide a source of food, employment, recreation and residence, and are the first defense from various natural and man-made hazards and disasters. Maintaining these as functional and healthy ecosystems is essential for our future well-being. Currently $50 \%$ of the world population lives in towns and cities within $100 \mathrm{~km}$ of the coast [1]. These coastal areas are impacted through pollution inputs due to changes in land use and hydrology, with vast amounts of our wastes entering on a daily basis. Ocean and estuarine ecosystems can therefore impact the extent to which humans are exposed to microbial pathogens, which include both marine-indigenous pathogens and externally introduced microbial contaminants. These pathogens can be found in association with marine animals, phytoplankton, zooplankton, sediments and detritus. Environmental factors, including salinity, temperature, nutrients and light, influence the survival and sometimes the proliferation of pathogens.

Recent research relating oceans and human health is addressing a range of issues in environmental health microbiology (Figure 1), including examinations of the sources and sinks of pathogens, human exposures, effects of development and management practices, and the expression of disease. New detection methods have been developed and tested, which represent not only a comparison of different approaches but take into account idiosyncrasies of different geographical areas (e.g. tropical vs. temperate regions), as well as the standardization of sample collection and processing methods. This work has broadened our perspectives on the types of microbial pathogens present in the ocean and the importance of non-point sources of contamination in the environment. In this manuscript we present several of the current challenges to understanding the impacts of microbes of public health concern in the coastal environment, including (1) indicator organisms, and their relationship to water quality, (2) non-point sources of contamination, (3) direct pathogen detection, (4) virulence, (5) non-enteric diseases resulting from recreational water use, (6) animals and environments as sentinels of water quality, and (7) zoonotic and emerging diseases.

\section{Discussion Water quality and indicators of fecal contamination}

The Clean Water Act (CWA), as amended by the Beaches Environmental Assessment and Coastal Health (BEACH) Act of 2000, requires coastal and Great Lakes states and territories to adopt bacterial water standards as protective as EPA's 1986 bacterial standards [2]. These standards are based on concentrations of fecal indicator bacteria (FIB) such as E. coli or enterococci. However, monitoring for these indicators is not always effective for determining when streams and coastal waters are contaminated with sewage because FIB can take up residence in the environment and may even multiply under certain conditions. Another problem with current water quality standards is the known difference between fate and transport characteristics of FIB compared to pathogens. Indicator bacteria are more sensitive to inactivation through treatment processes and have also been shown to be more sensitive to inactivation by sunlight than viral and protozoan pathogens. Sunlight inactivation varies seasonally, daily and at different geographic and climatic regions [3]. As a result, the concentrations of FIB in water samples measured after disinfection or measured in environmental waters are not reliable assurances that human pathogens in water have been reduced to levels that will not cause infections in swimmers [4].

Additional issues regarding the use of indicators occur with regard to the sample substrate and the sources of contamination. For over three decades, beach sands and sediments in tropical and subtropical environments have been documented to contain high concentrations of bacterial indicators. Studies conducted in Hawaii and Guam [5-7] and in Puerto Rico [8] have shown that in the absence of any known sources of human/animal waste, enterococci and E. coli are consistently present and recovered in high concentrations. In South Florida, river bank soils and beach sands have been implicated as the source of indicator microbes to the water column [9-11], and experimentation has documented that soil moisture mediated by tidal cycles is a key factor in facilitating regrowth [12]. Turnover due to current may also play an important role. Subsurface sands and sediments may serve as a refuge and a source when sands are reworked by wave action or erosion.

The significance of beach sands and other environmental sources is not necessarily limited to the sub-tropics. For 


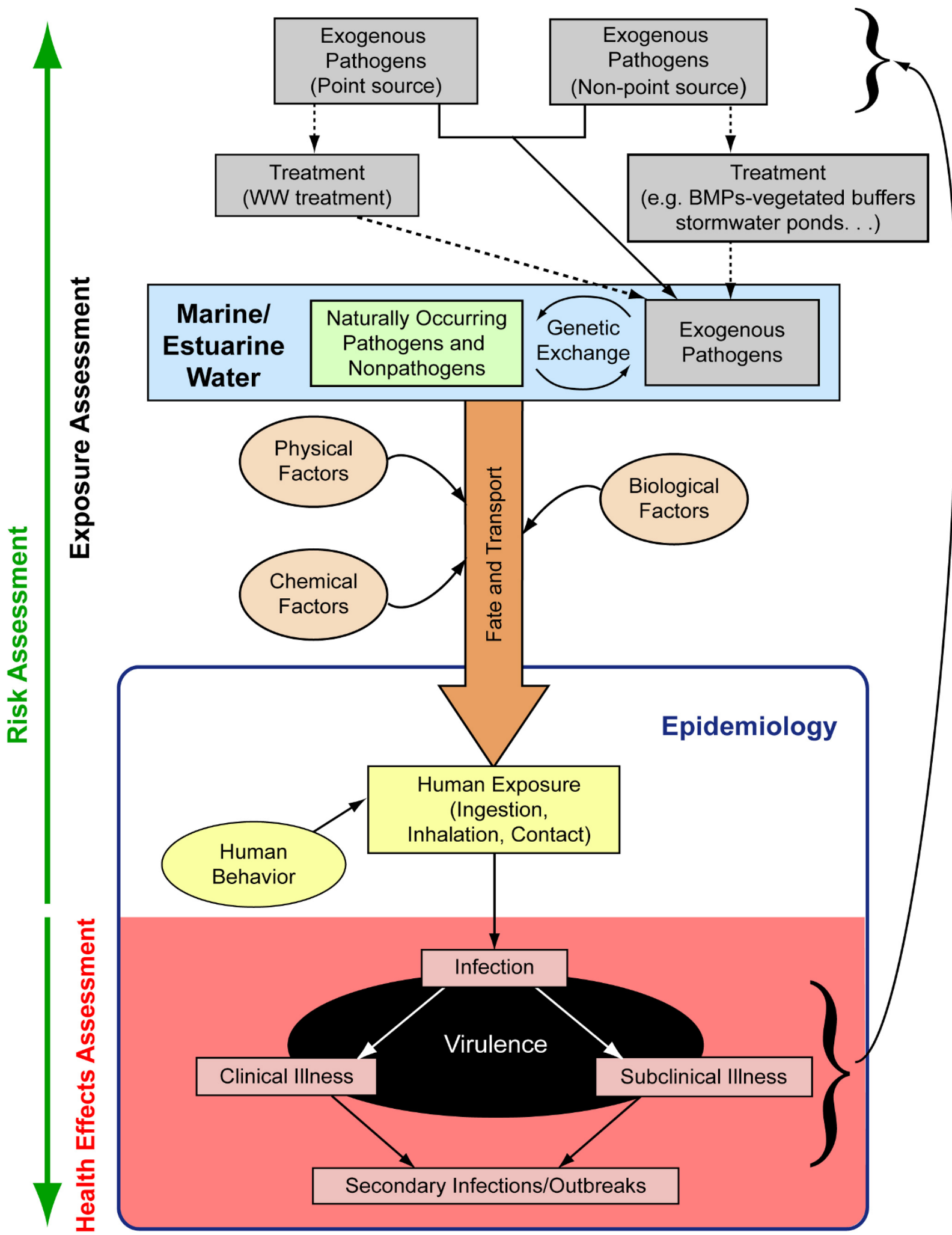

Figure I

Relationships between pathogens, the environment and human health. WW treatment $=$ wastewater treatment; BMPs = best management practices. 
example, sands and sediments have been implicated as a bacterial source at marine beaches in California [13-16] and at freshwater beaches of Lake Michigan [17], Lake Huron [18] and Lake Superior [19]. Again, soil moisture has been implicated in persistence and possible regrowth of indicator microbes [20]. More recently, aquatic plants including Cladophora [21] and epilithic periphyton communities [22] have also been identified as potential contributors to fecal indicator persistence and regrowth in temperate regions.

Alternative indicators are being proposed and evaluated to better identify risks to human health and to improve monitoring strategies. Ideally, these alternative indicators cannot multiply under environmental conditions, are present in low concentrations in unimpacted environmental samples, and are present in high concentrations in sewage. Proposed alternatives include bifidobacteria [23], Clostridium perfringens [24], human viruses [25] and FRNA coliphages [26]. The validation of new water quality indicators requires the correlation of the presence and abundance of the organism with human disease, often gastroenteritis. These correlations are made through epidemiology studies where study subjects (beach goers) report on disease symptoms and severity, and measurements of the organisms in the environment are conducted (Figure 2). It is expected that these techniques for identifying fecal contamination will allow for improved risk assessments and more informed monitoring.

Alternative indicators are also being proposed to help track sources of fecal pollution. Microbial source tracking methods are commonly classified as library-dependent or library-independent. A library is a database of characteristics (e.g. genetic fingerprints, antibiotic resistance profiles) of microbes from known sources. In librarydependent analyses, characteristics of isolates from contaminated waters are compared to the library to find matches, thereby identifying the source of contamination. Library-independent approaches entail analysis of water samples for source-specific markers (e.g. human-specific bacterial strains) to help identify sources. These approaches do not require building and maintenance of representative databases for each study area. Appropriate study design and application of microbial source tracking tools can be complicated, particularly for library-based methods $[29,30]$. However, source tracking technologies are rapidly advancing and can already provide useful insight for managers trying to mitigate contamination.

\section{Non-point sources of contamination}

Non-point sources of contamination are of significant concern with respect to the transport of pathogens and their indicators into the marine environment. Point source pollution enters the environment at a distinct loca-
Historically, bathing beach epidemiology studies conducted in the United States have focused on point source fecal contamination, i.e. studies have been conducted on beaches that have a known human sewage source contributing to their water quality degradation. However, the US EPA currently estimates that $60-80 \%$ of the impaired waters in the USA are impaired due to non-point source inputs, and recent evidence suggests there is no correlation between increasing concentrations of FIB in recreational waters and illness rates among swimmers at beaches impacted by nonpoint source contamination $[27,28]$. Researchers coordinated by the Southern California Coastal Water Research Project (SCCWRP) and US EPA are evaluating the links between novel microbial detection technologies and human health outcomes at beaches contaminated with non-point sources of pollution. Researchers at the University of Miami are further planning an epidemiology study using a randomized trial approach for a beach impacted with non-point source pollution in Florida in collaboration with the US Centers for Disease Control and Prevention. This research is expected to identify new indicators for predicting swimmer health risk and could help provide the basis for improved bathing beach standards.

\section{Figure 2}

Bathing beach epidemiology studies. References $[27,28]$.

tion through a direct route that is often easily identified, while non-point source pollution is generally diffuse and intermittent in nature, and occurs through a non-direct route. Examples include runoff from urban and agricultural areas, leaking septic systems and sewerage lines, combined sewer overflows, discharges from boats and atmospheric deposition of aerosols. We currently have a limited understanding of the actual pathogen loading of the coastal environment due to non-point source contamination, nor do we fully understand the consequences of this loading. Addressing non-point source contamination is one of the main challenges for future research. Further assessment of the effect of non-point sources on the loading of pathogens in the marine environment needs to include not only pathogen abundance, but an indication of the potential risk to human health and the ability to track the source of contamination.

Swimmers may themselves be sources of microbes in water. Bather shedding studies conducted in freshwater 
have long shown that humans release significant numbers of microbes, in particular enterococci and Staphylococcus aureus [31-33]. Elmir et al. [34] conducted the first experimental human bathing study in marine waters, and results were consistent with those found in freshwater (Figure 3). As $S$. aureus is isolated from human sewage in relatively low numbers $\left(10^{3} \mathrm{CFU} / 100 \mathrm{ml}\right)$ relative to enterococci $\left(10^{4}\right.$ to $\left.10^{5} \mathrm{CFU} / 100 \mathrm{ml}\right)$ [35], it can be used as an indicator to predict human bather impacts, which would include the combined effects of bather density, mixing, and dilution. The use of $S$. aureus as a potential supplemental indicator is especially significant as studies have shown an association between illness in swimmers and bather density $[30,36]$.

\section{Direct pathogen detection}

Given that presence and prevalence of indicators does not often correlate well with risk of infection from environmental pathogens, direct monitoring for pathogens is often suggested. Detection of pathogens from environmental samples is gaining momentum through the development of molecular technologies (Figure 4). Approaches are typically based upon measurement of specific sequences of nucleic acids (DNA or RNA), or through structural recognition of pathogens or biomarkers [38]. While the detection of pathogen DNA is not necessarily indicative of viability or even infectivity, it does represent a rapid and specific method. Probably the most popular methodology involves using the polymerase chain reaction (PCR) to amplify nucleic acids to detectable levels.

Bather shedding studies carried out at a beach in Miami-Dade County, FL [34] found that S. aureus was shed at levels one order of magnitude greater (5.5 x $10^{6}$ CFU per subject weighted based upon number of subjects per study) than enterococci (5.4 x $10^{5} \mathrm{CFU}$ per subject). Given these numbers, one human subject, on average, would release enough microbes such that 520 liters of water exceed US EPA's single sample regulatory guideline of 104 enterococci per $100 \mathrm{ml}$ of marine water [37]. In that same volume of water, a human subject would contribute $1100 \mathrm{~S}$. aureus per $100 \mathrm{ml}$, on average. Natural decontamination through dilution, sunlight inactivation and protist grazing help to mitigate bather inputs, however, these contributions from humans may be significant in relatively stagnant waters impacted by high bather loads.

\section{Figure 3}

Marine bather shedding study. References [34,37].
This technology is allowing researchers to rapidly and specifically target microbes of public health concern, including those that were previously unexamined because of our inability to culture them. New molecular assays have been introduced for detection of FIB $[39,40]$, bacterial pathogens $[41,42]$, viral pathogens $[25,43]$, and protozoan parasites [44,45]. Additionally, recent improvements in detection technologies are allowing simultaneous detection of multiple targets in a single assay [[46-49]; Figure 5]. As with new indicators, nucleic acid based detection of specific pathogens will need to go through testing to determine what level of detection is associated with unacceptable human health risk.

Despite the advances in detection technologies, sample collection and processing remains an issue for direct pathogen detection [51,52]. Improved filtration methods [53], electrochemical methods [49], immunochemical methods [54-56] and nanotechnologies [57,58] may enable better cell sorting and improve microbial isolation techniques, but each of these has its own challenges to overcome. Low recovery efficiencies associated with concentrating cells and extracting nucleic acids continue to decrease overall sensitivity for molecular targets. Isolation of microbes from complex samples is also problematic. Soil and sediment samples show high levels of heterogeneity and vary significantly with regard to physical and chemical composition, making the establishment of standardized protocols problematic. These variables represent challenges not only for quantitative recovery of nucleic acids, but for enzymatic manipulation of the resulting sample. Regardless, it is imperative that researchers calculate recovery efficiencies for their concentration and nucleic acid extraction protocols, and for amplification or other detection steps. Further, inhibition of PCR or other reactions should be quantified with an internal control, and concentration estimates should be appropriately adjusted.

It remains to be determined how direct pathogen detection and more rapid technologies will alter monitoring strategies. Given the advances made in measurements during the last two decades, monitoring programs will likely include measurements for a suite of microbes. A tiered monitoring strategy may also be a viable option [14]. In a tiered approach, the first step could involve using the simplest and most practical tests for contamination, perhaps utilizing a rapid test for fecal indicators. Tier two may involve adding methods to differentiate human from animal sources of pollution, and the tier three test, if necessary, would measure for specific pathogens. Supplemental microbial measurements could also be added, including indicators of disease transmitted via other routes of infection, including respiratory routes (e.g. adenovirus, Legionella), direct human shedding (e.g. S. 

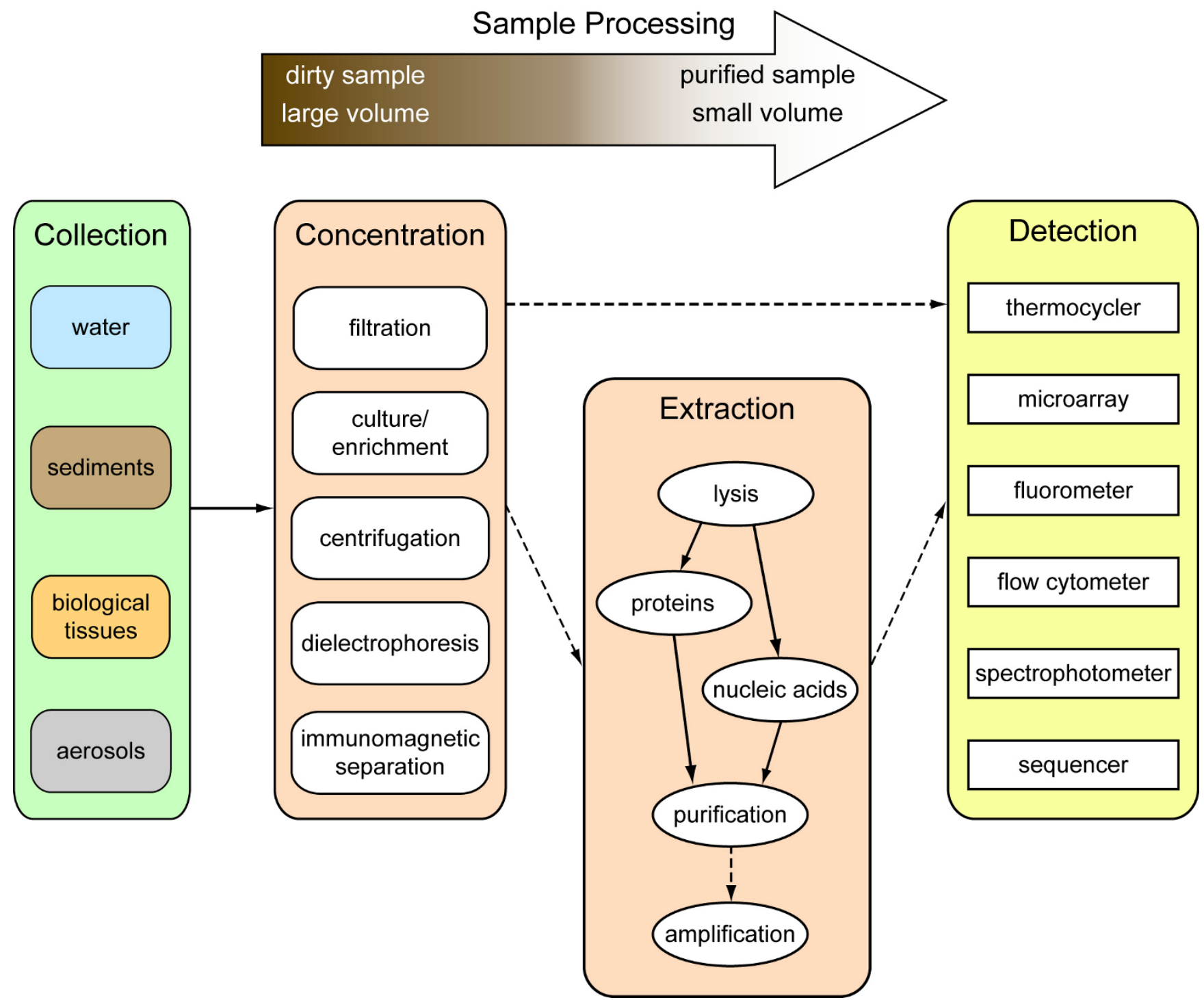

Figure 4

Common approaches for molecular detection of pathogens from environmental samples. It is important to use appropriate controls and to quantify recovery efficiencies of each step depicted.

aureus), and oral ingestion or wound infections from indigenous microbes (e.g. Vibrio). This tiered approach would not necessarily be appropriate for characterization of transient events, unless samples are appropriately archived for each level of analysis.

\section{Understanding virulence}

Methodologies that simply identify the presence of a pathogenic species in many cases may not improve existing tools since not all strains of infectious bacteria are equally pathogenic. Strain variation can arise through several mechanisms, including mutation, genomic rearrangements, inter and intragenic recombination, or acquisition of genes from mobile genetic elements including trans- ducing bacteriophages. Maintenance of these genetic changes occurs if they result in a selective advantage for survival in a given environmental niche $[59,60]$. Therefore, while a significant proportion of the population may not be virulent, there is always the potential for emergence of more infectious strains. This pattern of virulence is especially true of many marine bacteria including members of the Vibrio spp. For example, the majority of environmental $V$. cholerae strains are non-toxigenic and do not cause disease unless the cholera toxin gene is acquired via phage transduction [61]. Strains of the shellfish-borne pathogen $V$. vulnificus can now be genetically differentiated into one group more likely to cause clinical infections and another group that is less infectious and forms 
DNA microarrays can simultaneously monitor the presence of thousands of distinct sequences and thus represent a powerful tool for environmental monitoring of bacteria. However, their sensitivity is generally not sufficient to reliably detect pathogens in complex microbial communities. Researchers have recently developed a protocol that enables accurate identification of specific sequences in natural samples by a novel deconvolution algorithm [50]. Applied to environmental samples, the microarrays are able to detect Vibrio cholerae rRNA at natural concentrations $(0.05 \%$ of the total community) in New England estuarine water suggesting that microarrays may be applicable to broad environmental monitoring of co-occurring pathogens. Nonetheless, for some pathogens with very low infectious dose (e.g. 1-10 cells), current detection limits will still have to be improved; alternatively, pre-amplification of $\mathrm{rRNA}$ might be employed to raise detection limits.

\section{Figure 5}

Pushing the limits of DNA microarrays. Reference [50].

the majority of environmental strains [62-65]. Similarly, while $V$. parahaemolyticus is ubiquitous and often found in shellfish during harvest periods, relatively few genotypically distinct strains are responsible for most outbreaks of human infections [66]. There also appears to be an increase or emergence of more virulent $V$. parahaemolyticus, with increasing numbers of human infections arising from ingestion of raw oysters containing relatively few bacteria, although increased exposure of susceptible populations may play a part as well. Regardless, rapid detection tools must not only be sensitive enough to identify low numbers of a pathogen, but also be discriminatory enough to detect the presence of specific strains of a pathogen capable of expressing virulence genes required for human infection. The application of comparative genomics with contemporary molecular pathogenesis and virulence studies will aid in the identification of genes that will serve as sensitive and accurate markers of risk [67].

Genomics is also assisting population level studies to estimate the extent to which genotypes associate with defined environmental microhabitats and the probability of genetic exchange (of virulence factors and other genes) among co-existing microbes [68]. Particularly important is the identification of environmental reservoirs of virulent strains (Figure 6). Indeed, pathogenicity towards humans likely arises among indigenous marine bacteria due to adaptation to a specific marine microhabitat rather
Research has for the first time identified specific population partitioning of pathogens among water column microhabitats [69]. Researchers separated water samples into fractions containing free-living and attached cells; and the latter were further subdivided into small and large particle, and zooplankton-associated. This formed the input to a mathematical model capable of identifying the number of differentiated populations and their environmental preferences. This research demonstrated that while many vibrio species appear to display specialized habitat association, populations related to $V$. parahaemolyticus, which contain agents of shellfish poisoning, are generalists simultaneously occupying multiple environmental habitats. These findings will enable further exploration of genome diversity and patterns of gene flow among co-existing genomes, including the presence and transfer of pathogenicity determinant genes.

\section{Figure 6 \\ Population-level partitioning of vibrios among (micro) habitats in the water column. Reference [69].}

than selection for infection of the human body. This is because there is insufficient feedback from infected humans to environmental populations of the pathogen (with perhaps the notable exception of cholera in epidemic areas) to act as positive selection on virulence genes. For example, a specific $V$. cholerae surface protein contributes to the ability of the bacterium to attach to the chitin exoskeleton of zooplankton [70], an important environmental survival mechanism. While the same protein has also been shown to aid attachment to the human gut mucosa [70], it can be argued that the primary selective driving force for increased attachment is microhabitat adaptation. Overall, the ability to evade predation or establish zoonotic associations may predestine a microbe's ability to infect humans, although this is currently poorly understood [38].

In addition to virulence factors, it is also important to understand how bio-signaling molecules and other chemical compounds affect pathogenicity. The marine microbial community is responsible for the synthesis of highly bioactive secondary metabolites. These compounds are used to communicate (quorum sensing), defend (toxicity), or otherwise provide a competitive advantage to a select community [71-73]. In some cases these compounds augment the chemical behavior of other chemical or biological processes. This is often observed in cases of biofilm formation and/or incorporation of metals into 
metabolites [74,75] where enhanced pathogenicity or antibiotic resistance has been noted $[76,77]$. For example, when a biofilm created by a given microbial community is removed, often times old generation antibiotics become effective. Previously they simply could not cross the film. Investigating the interaction of these chemicals is critical in understanding the role the microbial community plays in human health related issues.

\section{Non-enteric diseases from water or aerosol transmission}

There have been several epidemiology studies regarding the potential transmission of non-gastrointestinal illnesses associated with recreational use of water. While an increased risk of gastroenteritis for swimmers is often found, several non-enteric infections have also been associated with exposure, including respiratory illness, and ear, eye and skin infections [78-83]. In one study, 63.7\% of the 683 participants reporting illnesses indicated respiratory symptoms [79]. In most of these studies, the risk of non-enteric infections in swimmers increased with either exposure to urban runoff or declining water quality due to pollution or sewage.

Some pathogenic microorganisms are naturally present in freshwater environments (Aeromonas hydrophila, Naegleria fowleri, Legionella pneumophila), while other human pathogenic species are indigenous to marine and brackish waters (V. cholerae, $V$. vulnificus, $V$. parahaemolyticus, $V$. alginolyticus). Pathogens naturally present in water may be transmitted to humans via inhalation, contact or ingestion of water or contaminated food. Examples of sources of non-enteric pathogens in environmental waters include animal urine for Leptospira spp. and shedding from human skin for $S$. aureus. In addition, Khan et al. [84] have discovered Pseudomonas aeruginosa in open ocean environments. P. aerugionos $a$ is an opportunistic pathogen that has been regarded to be widely present in terrestrial and freshwater environments. This report further illustrates the potential significance of the ocean as a reservoir for pathogenic isolates of traditionally non-indigenous bacteria.

Another potential source of non-enteric pathogens are free-living amoebae. Free living amoebae are natural reservoirs of many types of bacteria such as Legionella spp., Burkholderia pickettii, Vibrio cholerae, Myobacterium avium and Listeria monocytogenes [85,86]. It is known that Acanthamoeba species are natural aquatic reservoirs of several intracellular pathogens such as Legionella, Chlamydia and Mycobacterium $[87,88]$. Laboratory studies with Acanthamoeba castellanii have shown the ability of Francisella tularensis, the agent of tularemia, to survive in amoebal cysts; however, the potential for its survival under various adverse conditions in these cysts needs to be examined [89]. Studies have also shown that naturally occurring marine amoebae can harbor some of these pathogens (Figure 7), but their prevalence and the extent to which they harbor other pathogens is unknown. Amoebae in cooling towers and water treatment facility biofilms are considered the primary reservoir for pathogenic legionellae, not only providing refuge for the bacteria but also enhancing the infectivity of the microbe $[92,93]$. The level of human health risk these associations represent from the marine environment is unknown, and part of this problem is potentially the lack of correlation between marine exposure and the onset of symptoms several days to a week later.

Studies on the ecology and distribution of non-enteric pathogens in the marine environment are necessary to understand their potential threat to human health. Yet one of the biggest challenges remains effective monitoring. When the source of the etiological agents for nonenteric diseases is not fecal in origin, traditional monitoring for FIB will unlikely be successful in predicting the presence or absence of these pathogens. Although for many non-enteric pathogens there are methods for their specific detection and quantification from natural samples, there are no standards relevant for predicting the level of risk for human infection. Thus, research should be targeted towards establishing these standards for nonenteric pathogens where appropriate, or else efforts should be made toward public education about infections where human behavior plays a key role.

\section{Sentinel species and sentinel habitats}

A variety of marine species and habitats are excellent indicators or sentinels of environmental stress and potential health threats for humans. They provide information

Legionella pneumophila is the bacterium responsible for Legionnaires' disease. Infection with L. pneumophila results from the airborne spread of bacteria from an environmental reservoir to the human respiratory system. Protozoa are the most important environmental reservoirs for the survival and growth of Legionella in aquatic systems [90]. Researchers have also detected Legionella in amoeba cultures and sediment samples from the coastal marine environment of Mt. Hope Bay, MA. The prevalence of potentially pathogenic legionellae such as L. pneumophila in marine environments may indicate a potential human health issue [91].

\section{Figure 7}

Legionella pneumophila in the marine environment. References [99,91]. 
about how events in the environment may affect humans and animals. Sentinel species and habitats fall into at least three categories: (1) wildlife or habitats that tend to "sample" or concentrate contaminants, toxins, and/or pathogens from their environment and thus may provide more biologically relevant indicators of possible effects than water sampling alone; (2) wildlife with diets and/or physiologies at least partially similar to those of humans and which therefore may demonstrate early indications of potential health effects of environmental levels of contaminants, toxins and pathogens before they show up in humans (a biological early warning system); and (3) habitats that encompass key ecosystem components and are subjected to early and often high pollution exposure, thereby indicating potential effects at systems or community levels and on people.

\section{Biologically relevant sentinels in the environment}

Once pathogens enter the marine environment, they can be further concentrated by the action of filter feeding organisms such as mussels, clams and oysters. Mussels and oysters, in particular, are implicated more than any other marine animal in seafood illnesses. Since they are sessile filter feeders inhabiting the benthic environment, they bioaccumulate both metal and organic contaminants $[94,95]$, as well as concentrate microbial organisms including human pathogens [96-99]. The evaluation of the presence and distribution of pathogens among marine bivalves is critical to determining the present and future risk to human health by better understanding the nature of the interaction between pathogens and shellfish.

\section{Potential effects of environmental contamination}

Marine organisms, particularly marine mammals, can also be sensitive sentinel species to warn of impending human health problems from ocean-borne pathogens. Causes of mass mortality events in marine mammals have included viruses, bacteria and protozoa [100]. Monitoring for either emerging or recurring health problems in marine animals may provide information that can be used as a measure of ocean health that could also indicate the potential for future human health issues. The ability to use marine mammals as sentinels for pathogens important to ecosystem and human health requires appropriate tools and protocols to accurately test for and track those pathogens in sentinel populations and the ecosystem. In addition to being useful for detecting zoonotic diseases that can affect human health, marine mammals are also shown to be useful sentinel species for assessing health risks from natural toxins (i.e. algal toxins) and persistent chemical contaminants (e.g. polybrominated diphenyl ethers (PBDEs) and other organochlorines).

\section{Habitats}

Habitats serve as first repositories and impact zones for terrestrial runoff and thereby serve as sentinels of land-use impacts on adjacent coastal environments and human communities. One of the earliest symptoms of broad scale coastal ecosystem impairment has historically been declines in the amount and condition of critical habitats that are sensitive to changes in environmental conditions. Notable examples include sea grass beds, oyster reefs, kelp forests, coral reefs, and tidal creeks, including the estuarine wetlands associated with and draining into them. These sentinel habitats or first responders generally decline in extent and condition from years to decades before system-wide impairment is documented by routine environmental quality monitoring activities [101-103]. Unfortunately, the scientific knowledge to understand the warning signals provided by sentinel habitats has only recently become available [[104-107]; Figure 8].

While use of sentinel species and habitats provide many advantages over routine water and sediment sampling, they also have some important limitations. For example, migratory species such as some marine mammals, may integrate environmental conditions over a large coastal or ocean area, but may not provide as reliable information about specific localities. On the other hand, sedentary species such as oysters and specific local habitats like tidal creeks may give a very accurate picture of localized effects of contaminants, toxins and pathogens, but gaining a picture of more widespread impacts may require sampling of

Considerable advances have been made in assessing sentinel habitats using tidal creeks systems in the southeastern United States [108]. Tidal creeks are the primary connection between the land and estuaries, and they are dynamic environments renowned for their complexity, productivity, and role as critical nursery habitat for fisheries. Recent research has demonstrated that the headwater regions of urbanized creeks are the first indicators of water quality degradation such as high levels of bacterial and viral pathogens, and that creek sediments are repositories for much of the pollution released into the environment. Tidal creeks exhibit impairment years in advance of deeper open estuarine habitats and provide early warning of ecological and public health threats. They are the proverbial canary in the coalmine for coastal ecosystems.

\section{Figure 8}

Tidal creeks as sentinel habitats. Reference [108]. 
sentinels in numerous locations. Nonetheless, sentinels allow us to sample at several trophic levels and to develop understanding of how contaminants, toxins and pathogens may be passed, accumulated and/or biomagnified through food chains that include humans. Because they integrate the broad range of environmental conditions to which they are exposed, sentinel species and habitats can give a much better picture of the cumulative health effects of degraded coastal ecosystems than any other measure. They also provide unique opportunities to study how disease-causing materials may be passed directly from organism to organism and from mother to offspring, and the kinds of impacts associated with such passage, including cellular and gene-level responses. Such studies are generally much more difficult to conduct in humans.

\section{Zoonotic and emerging diseases}

An estimated $75 \%$ of emerging infectious diseases are zoonotic [109], and anthropogenic influence on ecosystems appears to be a common factor in the emergence and reemergence of zoonotic pathogens [110]. In the marine environment proper, bacterial, viral, fungal and protozoal pathogens that can infect humans have been detected in a range of marine animals, including pinnipeds, dolphins, cetaceans and otters (Figure 9). Bacteria such as Brucella, Leptospira and Mycobacterium have been shown to infect humans handling marine mammals [112,113], while others such as Clostridium, Burkholderia (formerly Pseudomonas), Salmonella and Staphylococcus have the potential to be transmitted to humans. Calicivirus and influenza A have been documented to occur in pinnipeds [114,115], and Blastomyces have been detected in dolphins [116]. California sea lions and ringed seals have been found to harbor G. lamblia and Cryptosporidium spp. $[117,118]$ and

A recent survey of marine mammals and birds in the Northeast United States has indicated that these organisms are exposed to, and likely carry, several zoonotic pathogens as well as antibiotic resistant bacteria [111]. Researchers have detected the presence of influenza, Giardia, Cryptosporidium, Brucella, and Leptospira in stranded, bycaught and live gulls, seals, dolphins, porpoises and whales. About half of the bacterial isolates from these organisms were resistant to at least one antibiotic, and over half of the resistant isolates showed resistance to four or more antibiotics routinely used in either human or terrestrial animal treatments.

\section{Figure 9}

Marine animal zoonoses. Reference [ $\mathrm{III}$.
Giardia cysts have been found in fecal material from harp seals (Phoca groenlandica), grey seals (Halichoerus grypus), and harbour seals (Phoca vitulina) from the St. Lawrence estuary in eastern Canada $[119,120]$. Pinnipeds have also been shown to harbor Salmonella and Campylobacter species, including strains that are resistant to multiple antibiotics $[121,122]$. Shorebirds are also potentially able to transmit parasites to humans. Canada geese carry several enteric human pathogens including G. lamblia, Camplyobacter jejuni and C. parvum $[123,124]$. Therefore, it seems possible that shorebirds feeding in an area that is contaminated by a sewer outfall may be yet another source of concentrated pathogen input to either shellfishing areas or recreational areas.

Analysis of the interaction between host animals (domesticated or wildlife) and the coastal watershed, the natural reservoirs in marine habitats, and the survival, prevalence and proliferation of the pathogens are a rational area of concern for disease emergence. New methods for direct or indirect detection of microorganisms are contributing to the detection of zoonoses $[125,126]$, but there is still a lack of understanding regarding the public health significance.

\section{Conclusion}

Oceans directly and indirectly impact the extent to which humans are exposed to disease-causing organisms. Recent research has greatly enhanced our understanding of the relationships between pathogens, coastal and marine environments, and human health. Assays for rapid detection of water-borne and shellfish-borne pathogens have been developed and optimized, and progress toward simultaneous and real-time detection is underway. Genetic factors associated with virulence are being discovered so that lethal strains can be specifically identified. Similarly, genetic targets are being revealed that help differentiate human from nonhuman sources of fecal contamination. Alternative indicators are being proposed to more accurately assess risks to human health, and new measures of contamination are being linked to health outcomes to help improve management criteria. In some instances, marine organisms and coastal habitats act as reservoirs for newly-introduced terrestrial pathogens and can contribute to disease transmission. These organisms and habitats are acting as sentinels for health status within a given ecosystem and can also help warn of threats from emerging pathogens. Overall, this research is leading to a greater understanding of how oceans affect human health, and how humans themselves influence this process.

\section{List of abbreviations used}

US EPA: United States Environmental Protection Agency; FIB: fecal indicator bacteria. 


\section{Competing interests}

The authors declare that they have no competing interests.

\section{Authors' contributions}

This manuscript was originally conceived during a breakout session at an Oceans and Human Health Initiative Center Directors Meeting held in Woods Hole, MA in April 2007. All of the listed authors then contributed text, and Rebecca Gast and Jill Stewart served to compile and edit the resulting document. All authors read and approved the final manuscript.

\section{Acknowledgements}

The Oceans and Human Health Initiative research described within this paper is supported by the National Science Foundation, The National Institute for Environmental Health Sciences and the National Oceanic and Atmospheric Administration. The authors thank Karen Swanson for helping to create Figures I and 4; and two reviewers for their helpful comments and suggestions. Grant numbers are: NIEHS P5O ESOI 2742 and NSF OCE043072 (RJG, LAA-Z, MFP), NSF OCE04-32479 and NIEHS P50 ESOI 2740 (RSF), NSF OCE-0432368 and NIEHS P50 ESI 2736 (HMS-G), NIEHS P50 ESOI 2762 and NSF OCE-0434087 (JSM).

This article has been published as part of Environmental Health Volume 7, Supplement 2, 2008: Proceedings of the Centers for Ocean and Health Investigators Meeting. The full contents of the supplement are available online at http://www.ehjournal.net/supplements/7/S2.

\section{References}

I. Shuval H: Thalassogenic infectious diseases caused by wastewater pollution of the marine enviornment. In Oceans and Health: Pathogens in the Marine Environment Edited by: Belkin S, Colwell RR. New York: Springer; 2006:373-389.

2. USEPA: Ambient water quality criteria for bacteria-1986. Washington, D.C.: U.S. Environmental Protection Agency Office of Water; 1986:18.

3. Fujioka RS, Yoneyama BS: Sunlight inactivation of human enteric viruses and fecal bacteria. Water Sci Technol 2002, 46(I I-I 2):29|-295.

4. Blatchley ER 3rd, Gong WL, Alleman JE, Rose JB, Huffman DE, Otaki $M$, Lisle JT: Effects of wastewater disinfection on waterborne bacteria and viruses. Water Environ Res 2007, 79(I):8I-92.

5. Fujioka RS, Roll BM: Sources of fecal indicator bacteria in a brackish, tropical stream and their impact on recreational water quality. Water Sci Technol 1997, 35(I I-I 2): I79-I86.

6. Fujioka RS, Sian-Denton C, Borja M, Castro J, Morphew K: Soil: the environmental source of Escherichia coli and Enterococci in Guam's stream. I Appl Microbiol Sympos Suppl 1999, 85:83S-89S.

7. Fujioka RS, Tenno K, Kansako S: Naturally occurring fecal coliforms and fecal streptococci in Hawaii's freshwater streams. Toxicity Assessment 1988, 3(5):613-630.

8. Toranzos GA, Marcos RP: Human enteric pathogens and soilborne disease. In Soil Biochemistry Volume 10. Edited by: Bollag $M$ Stotzky G. New York: Marcel Dekker; 2000:46I-48I.

9. Desmarais TR, Solo-Gabriele HM, Palmer CJ: Influence of soil on fecal indicator organisms in a tidally influenced subtropical environment. Appl Environ Microbiol 2002, 68(3): I I 65- I I 72.

10. Bonilla TD, Nowosielski K, Cuvelier M, Hertz A, Green M, Esiobu N, McCorquodale DS, Fleisher JM, Rogerson A: Prevalence and distribution of fecal indicator organisms in South Florida beach sand and preliminary assessment of health effects associated with beach sand exposure. Mar Pollut Bull 2007, 54(9): | 472-| 482.

II. Shibata T, Solo-Gabriele HM, Fleming LE, Elmir S: Monitoring marine recreational water quality using multiple microbia indicators in an urban tropical environment. Water Res 2004, 38(13):3| $19-3|3|$.
12. Solo-Gabriele HM, Wolfert MA, Desmarais TR, Palmer Cl: Sources of Escherichia coli in a coastal subtropical environment. Appl Environ Microbiol 2000, 66(I):230-237

13. Grant SB, Sanders BF, Boehm AB, Redman JA, Kim JH, Mrse RD, Chu AK, Gouldin M, McGee CD, Gardiner NA, et al.: Generation of enterococci bacteria in a coastal saltwater marsh and its impact on surf zone water quality. Environ Sci Technol 200I, 35( I 2):2407-24 I6.

14. Boehm AB, Fuhrman JA, Mrse RD, Grant SB: Tiered approach for identification of a human fecal pollution source at a recreational beach: case study at Avalon Bay, Catalina Island, California. Environ Sci Technol 2003, 37(4):673-680.

15. Yamahara KM, Layton BA, Santoro AE, Boehm AB: Beach sands along the California coast are diffuse sources of fecal bacteria to coastal waters. Environ Sci Technol 2007, 4 I ( I 3):45 I 5-452 I.

16. Lee CM, Lin TY, Lin CC, Kohbodi GA, Bhatt A, Lee R, Jay JA: Persistence of fecal indicator bacteria in Santa Monica Bay beach sediments. Water Res 2006, 40(I4):2593-2602.

17. Whitman RL, Nevers MB: Foreshore sand as a source of Escherichia coli in nearshore water of a Lake Michigan beach. Appl Environ Microbiol 2003, 69(9):5555-5562.

18. Alm EW, Burke J, Hagan E: Persistence and potential growth of the fecal indicator bacteria, Escherichia, in shoreline sand at Lake Huron. J Great Lakes Res 2006, 32:40I-405.

19. Ishii S, Hansen DL, Hicks RE, Sadowsky MJ: Beach sand and sediments are temporal sinks and sources of Escherichia coli in Lake Superior. Environ Sci Technol 2007, 4 I (7):2203-2209.

20. Beversdorf LJ, Bornstein-Forst SM, McLellan SL: The potential for beach sand to serve as a reservoir for Escherichia coli and the physical influences on cell die-off. J Appl Microbiol 2007, I02(5): |372-|38|

21. Whitman RL, Shively DA, Pawlik H, Nevers MB, Byappanahalli MN: Occurrence of Escherichia coli and enterococci in Cladophora (Chlorophyta) in nearshore water and beach sand of Lake Michigan. Appl Environ Microbiol 2003, 69(8):47| 4-47I9.

22. Ksoll WB, Ishii S, Sadowsky MJ, Hicks RE: Presence and sources of fecal coliform bacteria in epilithic periphyton communities of Lake Superior. Appl Environ Microbiol 2007, 73(I 2):377I-3778.

23. Rhodes $M W$, Kator $H$ : Sorbitol-fermenting bifidobacteria as indicators of diffuse human faecal pollution in estuarine watersheds. J Appl Microbiol I999, 87(4):528-535.

24. Fujioka RS: Monitoring coastal marine waters for spore-forming bacteria of faecal and soil origin to determine point from non-point source pollution. Water Sci Technol 200I, 44(7): $|8|-188$

25. Gregory JB, Litaker RW, Noble RT: Rapid one-step quantitative reverse transcriptase $P C R$ assay with competitive internal positive control for detection of enteroviruses in environmental samples. Appl Environ Microbiol 2006, 72(6):3960-3967.

26. Luther K, Fujioka R: Usefulness of monitoring tropical streams for male-specific RNA coliphages. J Water Health 2004, 2(3): $|7|-|8|$

27. Colford JM Jr, Wade TJ, Schiff KC, Wright CC, Griffith JF, Sandhu SK, Burns S, Sobsey M, Lovelace G, Weisberg SB: Water quality indicators and the risk of illness at beaches with nonpoint sources of fecal contamination. Epidemiology 2007, I 8(I):27-35

28. Calderon RL, Mood EW, Dufour AP: Health effects of swimmers and nonpoint sources of contaminated waters. Int J Environ Health Res 1991, I:21-31.

29. Stoeckel DM, Harwood VJ: Performance, design, and analysis in microbial source tracking studies. Appl Environ Microbiol 2007, 73(8):2405-24I5.

30. Field KG, Samadpour M: Fecal source tracking, the indicator paradigm, and managing water quality. Water Res 2007, 4 I ( I 6):35I7-3538

31. Smith BG, Dufour AP: Effects of the microbiological quality of recreational waters: A simulation study. American Society for Microbiology 93rd General Meeting: May 16-20 1993; Atlanta, GA 1993.

32. Hanes NB, Fossa AJ: A qualitative analysis of the effects of bathers in recreational water quality. Adv Water Pollut Res 1970, 5:9/ I-9/9.

33. Robinton ED, Mood EW: A quantitative and qualitative appraisal of microbial pollution of water by swimmers. A preliminary report. J Hyg (Lond) 1966, 64(4):489-499.

34. Elmir SM, Wright ME, Abdelzaher A, Solo-Gabriele HM, Fleming LE, Miller G, Rybolowik M, Peter Shih MT, Pillai SP, Cooper JA, et al.: 
Quantitative evaluation of bacteria released by bathers in a marine water. Water Res 2007, 4I (I):3-I0.

35. Gerba CP: Assessment of enteric pathogen shedding by bathers during recreational activity and its impact on water quality. Quant Microbiol 2000, 2:55-68.

36. Charoenca N, Fujioka R: Association of staphylococcal skin infections and swimming. Water Sci Technol 1995, 31: I I-I7.

37. USEPA: Water quality standards for coastal and great lakes recreation waters. Federal Register November 16 edition. 2004 69:67217-67243

38. Thompson JR, Marcelino LA, Polz MF: Diversity, sources and detection of human bacterial pathogens in the marine environment. In Oceans and Health: Pathogens in the Marine Environment Edited by: Belkin S, Colwell RR. New York: Springer; 2005:29-68.

39. Haugland RA, Siefring SC, Wymer LJ, Brenner KP, Dufour AP: Comparison of Enterococcus measurements in freshwater at two recreational beaches by quantitative polymerase chain reaction and membrane filter culture analysis. Water Res 2005 , 39(4):559-568.

40. Griffith J, Weisberg SB: Evaluation of rapid microbiological methods for measuring recreational water quality. Westminster, CA: Southern California Coastal Water Research Project; 2006.

4I. Walters SP, Gannon VP, Field KG: Detection of Bacteroidales fecal indicators and the zoonotic pathogens $E$. coli 0I57:H7, Salmonella, and Campylobacter in river water. Environ Sci Technol 2007, 4I(6): 1856- |862.

42. Hsu WB, Wang JH, Chen PC, Lu YS, Chen JH: Detecting low concentrations of Shigella sonnei in environmental water samples by PCR. FEMS Microbiol Lett 2007, 270(2):29I-298.

43. He JW, Jiang S: Quantification of enterococci and human adenoviruses in environmental samples by real-time PCR. Appl Environ Microbiol 2005, 7 I (5):2250-2255.

44. Johnson DW, Pieniazek NJ, Griffin DW, Misener L, Rose JB: Development of a PCR protocol for sensitive detection of Cryptosporidium oocysts in water samples. Appl Environ Microbiol I 995, 6 I (I I ):3849-3855.

45. Guy RA, Payment P, Krull U], Horgen PA: Real-time PCR for quantification of Giardia and Cryptosporidium in environmental water samples and sewage. Appl Environ Microbiol 2003 69(9):5178-5।85.

46. Maynard C, Berthiaume F, Lemarchand K, Harel J, Payment P, Bayardelle $P$, Masson L, Brousseau R: Waterborne pathogen detection by use of oligonucleotide-based microarrays. Appl Environ Microbiol 2005, 7 I(I 2):8548-8557.

47. Straub TM, Dockendorff BP, Quinonez-Diaz MD, Valdez CO, Shutthanandan JI, Tarasevich BJ, Grate JW, Bruckner-Lea CJ: Automated methods for multiplexed pathogen detection. J Microbiol Methods 2005, 62(3):303-316.

48. Baums IB, Goodwin KD, Kiesling T, Wanless D, Diaz MR, Fell JW: Luminex detection of fecal indicators in river samples, marine recreational water, and beach sand. Mar Pollut Bull 2007, 54(5):52I-536.

49. LaGier M], Fell JW, Goodwin KD: Electrochemical detection of harmful algae and other microbial contaminants in coastal waters using hand-held biosensors. Mar Pollut Bull 2007, 54(6): 757-770.

50. Marcelino LA, Backman V, Donaldson A, Steadman C, Thompson JR, Preheim SP, Lien C, Lim E, Veneziano D, Polz MF: Accurately quantifying low-abundant targets amid similar sequences by revealing hidden correlations in oligonucleotide microarray data. Proc Natl Acad Sci USA 2006, 103 (37): | 3629-13634.

51. Straub TM, Chandler DP: Towards a unified system for detecting waterborne pathogens. J Microbiol Methods 2003, 53(2): $185-197$.

52. Noble RT, Weisberg SB: A review of technologies for rapid detection of bacteria in recreational waters. I Water Health 2005, 3(4):38I-392.

53. Abdelzaher A, Solo-Gabriele HM, Wright ME, Palmer C): Simultaneous concentration of bacteria and viruses from marine waters using a layered membrane system. J Environ Qual 2008 , 37(4): 1648-1655.

54. Fischer NO, Tarasow TM, Tok JB: Heightened sense for sensing recent advances in pathogen immunoassay sensing platforms. Analyst 2007, 132(3): 187-191.

55. Mulvaney SP, Cole CL, Kniller MD, Malito M, Tamanaha CR, Rife JC Stanton MW, Whitman LJ: Rapid, femtomolar bioassays in com- plex matrices combining microfluidics and magnetoelectronics. Biosens Bioelectron 2007, 23(2): 19|-200.

56. Guntupalli R, Hu J, Lakshmanan RS, Huang TS, Barbaree JM, Chin BA A magnetoelastic resonance biosensor immobilized with polyclonal antibody for the detection of Salmonella typhimurium. Biosens Bioelectron 2007, 22(7): | 474- 4479.

57. Gupta AK, Nair PR, Akin D, Ladisch MR, Broyles S, Alam MA, Bashir $\mathrm{R}$ : Anomalous resonance in a nanomechanical biosensor. Proc Natl Acad Sci USA 2006, I 03(36): I3362-I3367.

58. Liu Y, Chakrabartty S, Alocilja EC: Fundamental building blocks for molecular biowire based forward error-correcting biosensor. Nanotechnology 2007, 18:424017. 6pP.

59. Keymer DP, Miller MC, Schoolnik GK, Boehm AB: Genomic and phenotypic diversity of coastal Vibrio cholerae strains is linked to environmental factors. Appl Environ Microbiol 2007 73(II):3705-37I4

60. Miller MC, Keymer DP, Avelar A, Boehm AB, Schoolnik GK: Detection and transformation of genome segments that differ within a coastal population of Vibrio cholerae strains. Appl Environ Microbiol 2007, 73( I I):3695-3704.

6I. Faruque SM, Asadulghani, Saha MN, Alim AR, Albert MJ, Islam KM, Mekalanos Jj: Analysis of clinical and environmental strains of nontoxigenic Vibrio cholerae for susceptibility to CTXPhi: molecular basis for origination of new strains with epidemic potential. Infect Immun 1998, 66( I 2):5819-5825

62. Nilsson WB, Paranjype RN, DePaola A, Strom MS: Sequence polymorphism of the 16S rRNA gene of Vibrio vulnificus is a possible indicator of strain virulence. I Clin Microbiol 2003, 4 I ( I):442-446

63. Rosche TM, Yano Y, Oliver JD: A rapid and simple PCR analysis indicates there are two subgroups of Vibrio vulnificus which correlate with clinical or environmental isolation. Microbiol Immunol 2005, 49(4):38I-389.

64. Vickery MC, Nilsson WB, Strom MS, Nordstrom IL, DePaola A: A real-time PCR assay for the rapid determination of 165 rRNA genotype in Vibrio vulnificus. J Microbiol Methods 2007, 68(2):376-384.

65. Cohen AL, Oliver JD, DePaola A, Feil EJ, Boyd EF: Emergence of a virulent clade of Vibrio vulnificus and correlation with the presence of a 33-kilobase genomic island. Appl Environ Microbiol 2007, 73(I7):5553-5565.

66. DePaola A, Ulaszek J, Kaysner CA, Tenge BJ, Nordstrom JL, Wells J, Puhr N, Gendel SM: Molecular, serological, and virulence characteristics of Vibrio parahaemolyticus isolated from environmental, food, and clinical sources in North America and Asia. Appl Environ Microbiol 2003, 69(7):3999-4005

67. Paranjpye RN, Strom MS: A Vibrio vulnificus type IV pilin contributes to biofilm formation, adherence to epithelial cells, and virulence. Infect Immun 2005, 73(3): | |4| I- I 422.

68. Raskin DM, Seshadri R, Pukatzki SU, Mekalanos J]: Bacterial genomics and pathogen evolution. Cell 2006, I 24(4):703-7। 4.

69. Hunt DE, David LA, Gevers D, Preheim SP, Alm EJ, Polz MF: Resource partitioning and sympatric differentiation among closely related bacterioplankton. Science 2008, 320(5879): 108I-1085.

70. Kirn TJ, Jude BA, Taylor RK: A colonization factor links Vibrio cholerae environmental survival and human infection. Nature 2005, 438(7069):863-866.

7I. Altier C, Suyemoto M, Ruiz AI, Burnham KD, Maurer R: Characterization of two novel regulatory genes affecting Salmonella invasion gene expression. Mol Microbiol 2000, 35(3):635-646.

72. Loo CY, Corliss DA, Ganeshkumar N: Streptococcus gordonii biofilm formation: identification of genes that code for biofilm phenotypes. J Bacteriol 2000, | 82(5): | 374-| 382.

73. Bhagwat SP, Nary J, Burne RA: Effects of mutating putative twocomponent systems on biofilm formation by Streptococcus mutans UAI59. FEMS Microbiol Lett 200I, 205(2):225-230.

74. Maldonado MT, Hughes MP, Rue EL, Wells ML: The effect of Fe and $\mathrm{Cu}$ on growth and domoic acid production by Pseudonitzschia multiseries and Pseudo-nitzschia australis. Limnol Oceanogr 2002, 47(2):515-526.

75. Twiner MJ, Chidiac P, Dixon SJ, Trick CG: Extracellular organic compounds from the ichthyotoxic red tidal alga (Heterosigma akashiwo) elevate cytosolic calcium and induce apoptosis in Sf9 cells. Harmful Algae 2005, 4(4):789-800.

76. Collins M: Algal Toxins. Microbiol Rev 1978, 42(4):725-746. 
77. Gilbert PM, Burkholder JM, Parrow MW, Lewitus AJ, Gustafson DE: Direct uptake of nitrogen by Pfiesteria piscicida and Pfiesteria shumwayae, and nitrogen nutritional preferences. Harmful Algae 2006, 5(4):380-394.

78. Seyfried PL, Tobin RS, Brown NE, Ness PF: A prospective study of swimming-related illness. I. Swimming-associated health risk. Am J Public Health 1985, 75(9): I068-1070.

79. Corbett SJ, Rubin GL, Curry GK, Kleinbaum DG: The health effects of swimming at Sydney beaches. The Sydney Beach Users Study Advisory Group. Am J Public Health 1993, 83(I2): I $701-1706$.

80. Fleisher JM, Kay D, Salmon RL, Jones F, Wyer MD, Godfree AF: Marine waters contaminated with domestic sewage: nonenteric illnesses associated with bather exposure in the United Kingdom. Am J Public Health 1996, 86(9): | 228- 234.

8I. Haile RW, Witte JS, Gold M, Cressey R, McGee C, Millikan RC, Glasser A, Harawa N, Ervin C, Harmon P, et al: The health effects of swimming in ocean water contaminated by storm drain runoff. Epidemiology 1999, 10(4):355-363.

82. Prieto MD, Lopez B, Juanes JA, Revilla JA, Llorca J, Delgado-Rodriguez $M$ : Recreation in coastal waters: health risks associated with bathing in sea water. J Epidemiol Community Health 200I, 55(6):442-447.

83. Dwight RH, Baker DB, Semenza JC, Olson BH: Health effects associated with recreational coastal water use: urban versus rural California. Am J Public Health 2004, 94(4):565-567.

84. Khan NH, Ishii Y, Kimata-Kino N, Esaki H, Nishino T, Nishimura M, Kogure K: Isolation of Pseudomonas aeruginosa from open ocean and comparison with freshwater, clinical, and animal isolates. Microb Ecol 2007, 53(2): I 73-186.

85. Horn $M$, Wagner $M$ : Bacterial endosymbionts of free-living amoebae. J Eukaryot Microbiol 2004, 5 I(5):509-5I4.

86. Greub G, Raoult D: Microorganisms resistant to free-living amoebae. Clin Microbiol Rev 2004, I7(2):413-433

87. Amann R, Springer N, Schonhuber W, Ludwig W, Schmid EN, Muller $K D$, Michel R: Obligate intracellular bacterial parasites of Acanthamoebae related to Chlamydia spp. Appl Environ Microbiol 1997, 63(I):|1|5-121.

88. Winiecka-Krusnell J, Linder E: Bacterial infections of free-living amoebae. Res Microbiol 200I, I 52(7):6|3-6I 9.

89. Abd H, Johansson T, Golovliov I, Sandstrom G, Forsman M: Survival and growth of Francisella tularensis in Acanthamoeba castellanii. Appl Environ Microbiol 2003, 69(1):600-606.

90. Cirillo JD, Falkow S, Tompkins LS: Growth of Legionella pneumophila in Acanthamoeba castellanii enhances invasion. Infect Immun 1994, 62(8):3254-326I.

91. Cirillo JD, Cirillo SL, Yan L, Bermudez LE, Falkow S, Tompkins LS: Intracellular growth in Acanthamoeba castellanii affects monocyte entry mechanisms and enhances virulence of Legionella pneumophila. Infect Immun 1999, 67(9):4427-4434.

92. Atlas RM: Legionella: from environmental habitats to disease pathology, detection and control. Environ Microbiol 1999, I(4):283-293.

93. Gast RJ, Moran DM, Dennett MR, Rocca J, Amaral-Zettler L: Amoebae from saline environments harbor Legionella species. International Society of Protistologists Annual Meeting: August 5-9 2007; Warwick, RI 2007.

94. Viarengo A: Biochemical effects of trace metals. Mar Pollut Bull 1986, 16(4):153-158.

95. O'Connor TP, Lauenstein GG: Trends in chemical concentrations in mussels and oysters collected along the US coast: Update to 2003. Mar Environ Res 2006, 62:26I-285.

96. Colwell RR, Liston J: The natural bacterial flora of certain marine invertebrates. J Insect Pathol 1962, 4:23-33.

97. Kueh CS, Chan KY: Bacteria in bivalve shellfish with special reference to the oyster. J Appl Bacteriol I985, 59(I):4I-47.

98. Schets FM, Berg HHIL van den, Verschoor F, Engels GB, Lodder W], van Pelt-Heerschap HML, Geissen JWB van der, de Roda Husman AM, ven der Poel WHM: Detection of Cryptosporidium and Giardia in Portugese oysters (Crassostrea gigas) grown in the Oosterschelde, the Netherlands. In Cryptosporidium parvum in Food and Water Dublin: Teagasc; 2003:I 19.

99. Gomez-Couso H, Freire-Santos F, Amar CFL, Grant KA, Williamson $\mathrm{K}$, Ares-Mazas ME, McLaughlin J: Detection of Cryptosporidium and Giardia in samples of shellfish by PCR. In Cryptosporidium parvum in Food and Water Dublin: Teagasc; 2003: I I I.
100. Gulland FMD, Hall AJ: Is marine mammal health deteriorating? Trends in the global reporting of marine mammal disease. EcoHealth 2007, 4:135-150.

I0I. Bayley S, Stotts VD, Springer PF, Steenis J: Changes in submerged aquatic macrophyte populations at the head of the Chesapeake Bay 1958-1975. Estuaries 1978, I:74-85.

102. Dustan $\mathrm{P}, \mathrm{CHJ}$ : Changes in the reef-coral community of Carysfort Reef, Key Largo, Florida: 1974-1982. Coral Reefs 1987, 6:91-106.

103. Holland AF, Sanger DM, Gawle CP, Lerberg SB, Santiago MS, Riekerk GHM, Zimmerman LE, Scott GI: Linkages between tidal creek ecosystems and the landscape and demographic attributes of their watersheds. J Exp Mar Biol Ecol 2004, 298: I5I-I78.

104. Kemp WM, Twilley RR, Stevenson JC, Boynton WR, Means JC: The decline of submerged vascular plants in upper Chesapeake Bay: Summary of results concerning possible causes. Mar Tech Soc J 1983, I7:78-89.

105. Hoegh-Guldberg O: Coral bleaching, climate change and the future of the world's coral reefs. Marine and Freshwater Research 1999, 50:839-866.

106. Porter JW, Tougas Jl: Reef ecosystems: Threats to their biodiversity. In Encyclopedia of Biodiversity Volume 5. Edited by: Levin S. San Diego: Academic Press; 200 I:73-95.

107. Turgeon DD, 37 other authors: The State of Coral Reef Ecosystems of the United States and Pacific Freely Associated States: 2002. Silver Spring, MD: National Oceanic and Atmospheric Administration/National Ocean Service/National Centers for Coastal Ocean Science; 2002:265

108. DiDonato GT, Stewart JR, Sanger DM, Robinson BJ, Thompson BC, Holland AF, Van Dolah R: Effects of changing land use on the microbial water quality of tidal creeks. Mar Pollut Bull in press.

109. Chomel BB, Belotto A, Meslin FX: Wildlife, exotic pets, and emerging zoonoses. Emerg Infect Dis 2007, I3(I):6-II.

110. Daszak P, Cunningham AA, Hyatt AD: Anthropogenic environmental change and the emergence of infectious diseases in wildlife. Acta Trop 200I, 78(2): $103-116$.

III. Bogomolni A, Ellis J, Gast RJ, Harris R, Pokras M, Touhey K, Moore MJ: Emerging zoonoses in marine mammals and seabirds of the Northeast U.S. Oceans '06: September I8-2I 2006; Boston, MA 2006.

112. Thompson PJ, Cousins DV, Gow BL, Collins DM, Williamson BH, Dagnia HT: Seals, seal trainers, and mycobacterial infection. Am Rev Respir Dis 1993, I47(I): I64-167.

113. Brew SD, Perrett LL, Stack JA, MacMillan AP, Staunton NJ: Human exposure to Brucella recovered from a sea mammal. Vet $R e c$ 1999, I 44( (17):483

1 14. Smith AW, Skilling DE, Cherry N, Mead JH, Matson DO: Calicivirus emergence from ocean reservoirs: zoonotic and interspecies movements. Emerg Infect Dis 1998, 4(I): I3-20.

115. Webster RG, Geraci J, Petursson G, Skirnisson K: Conjunctivitis in human beings caused by influenza $A$ virus of seals. $N$ Engl $J$ Med I98I, 304(15):911.

1 16. Cates MB, Kaufman L, Grabau JH, Pletcher JM, Schroeder JP: Blastomycosis in an Atlantic bottlenose dolphin. J Am Vet Med Assoc 1986, I89(9): I I48-II50.

117. Deng MQ, Peterson RP, Cliver DO: First findings of Cryptosporidium and Giardia in California sea lions (Zalophus californianus). J Parasitol 2000, 86(3):490-494

I 18. Appelbee AJ, Thompson RC, Olson ME: Giardia and Cryptosporidium in mammalian wildlife - current status and future needs. Trends Parasitol 2005, 2 I (8):370-376.

1 19. Olson ME, Goh J, Phillips M, Guselle N, McAllister TA: Giardia cyst and Cryptosporidium oocyst survival in water, soil, and cattle feces. J Environ Qual 1997, 28:199|-1996.

120. Measures LN, Olson M: Giardiasis in pinnipeds from eastern Canada. J Wildl Dis 1999, 35(4):779-782.

121. Johnson SP, Nolan S, Gulland FM: Antimicrobial susceptibility of bacteria isolated from pinnipeds stranded in central and northern California. J Zoo Wildl Med 1998, 29(3):288-294.

122. Stoddard RA, Gulland MD, Atwill ER, Lawrence J, Jang S, Conrad PA: Salmonella and Campylobacter spp. in northern elephant seals, California. Emerg Infect Dis 2005, II ( I 2): I 967-1969.

123. Graczyk TK, Fayer R, Trout JM, Lewis EJ, Farley CA, Sulaiman I, Lal AA: Giardia sp. cysts and infectious Cryptosporidium parvum oocysts in the feces of migratory Canada geese (Branto canadensis). Appl Environ Microbiol 1998, 64(7):2736-2738. 
124. Kuhn RC, Rock CM, Oshima KH: Occurrence of Cryptosporidium and Giardia in wild ducks along the Rio Grande River valley in southern New Mexico. Appl Environ Microbiol 2002, 68(I): $161-165$.

125. Murphy FA: Emerging zoonoses. Emerg Infect Dis 1998, 4(3):429-435

126. Bolin C, Brown C, Rose J: Emerging zoonotic diseases and water. In Waterborne Zoonoses Identification, Causes and Control Edited by: Cotruvo JA, Dufour A, Rees G, Bartram J, Carr R, Cliver DO, Craun GF, Fayer R, Gannon VPJ. Padstow, Cornwall, UK: T.J. International (Ltd); 2004:19-26.

Publish with Bio Med Central and every scientist can read your work free of charge

"BioMed Central will be the most significant development for disseminating the results of biomedical research in our lifetime. " Sir Paul Nurse, Cancer Research UK

Your research papers will be:

- available free of charge to the entire biomedical community

- peer reviewed and published immediately upon acceptance

- cited in PubMed and archived on PubMed Central

- yours - you keep the copyright

Submit your manuscript here:

http://www.biomedcentral.com/info/publishing_adv.asp
BioMedcentral 